\title{
Uptake of salmon-derived nitrogen by mosses and liverworts in coastal British Columbia
}

\author{
C. E. Wilkinson, M. D. Hocking and T. E Reimchen
}

Wilkinson, C. E., Hocking, M. D. and Reimchen, T. E. 2005. Uptake of salmon-derived nitrogen by mosses and liverworts in coastal British Columbia. - Oikos 108: 85-98.

\begin{abstract}
Throughout forested watersheds bordering the North Pacific, anadromous salmon (Oncorhynchus spp.) are transferred into coastal forests by numerous predators and scavengers with remnants providing an important nutrient subsidy to riparian zones. The contribution of these nutrients to mosses and liverworts, which are the dominant ground cover of coastal forests, has not been investigated. We examine here $\delta^{15} \mathrm{~N}$ isotope signatures and foliar percent $\mathrm{N}$ of eight moss and liverwort species, as well as moss and liverwort community structure, in multiple habitat blocks that vary in access to salmon nutrients from two watersheds on the central coast of British Columbia. For the most common moss Rhytidiadelphus loreus, we also examine $\delta^{15} \mathrm{~N}$ values and foliar percent $\mathrm{N}$ among salmon carcass micro-sites and along wildlife trails. Overall, $\delta^{15} \mathrm{~N}$ signatures ranged from $2 \%$ to $7 \%$ higher below the falls near the salmon stream than above the small falls that are impassable to salmon, or at the adjacent control watershed that had no salmon. Among micro-sites, $\delta^{15} \mathrm{~N}$ and $\% \mathrm{~N}$ values were highest near bony carcass remnants from transfer during previous years and high adjacent to wildlife trails indicating spatial heterogeneity in the salmon nutrient pools of these forests. Species richness and prevalence of nitrogen-rich soil indicators were also highest in forests adjacent to the salmon stream. These data suggest an important contribution of salmon-derived nutrients to the non-vascular plants of the riparian zone of old-growth forests throughout the Pacific Rim.
\end{abstract}

C. E. Wilkinson, M. D. Hocking and T. E. Reimchen, Dept of Biology, Univ. of Victoria, PO Box 3020, Victoria, British Columbia, Canada, V8W3N5 (reimchen@uvic.ca).

\section{Introduction}

Throughout the Pacific Rim, anadromous salmon (Oncorhynchus spp.) constitute an important seasonal pulse of nutrients for diverse taxa of marine, freshwater and terrestrial organisms (summarized by Cederholm et al. 2000). As well as subsidizing lake and stream food webs (Kline et al. 1990, 1993, Bilby et al. 1996, Wipfli et al. 1998, Chaloner et al. 2002), salmon nutrients also act as an important nutrient source for riparian vegetation (Ben-David et al. 1998, Helfield and Naiman 2001, Mathewson et al. 2003) and for multiple trophic levels in forest food webs adjacent to salmon streams (Hocking and Reimchen 2002, Reimchen et al. 2003).
Salmon-derived fertilization of coastal riparian zones can have multiple sources. Bears (Ursus arctos and $U$. americanus), which are abundant and widespread throughout the distribution of salmon, are major vectors through which salmon nutrients are transferred to the forest floor, either from direct carcass transfer (Reimchen 1994, 2000) or from urine and faeces deposition (Hilderbrand et al. 1999). Other predators such as wolves (Canis lupus) and river otters (Lutra canadensis) can have important local influences (Ben-David et al. 1997, Cederholm et al. 2000, Darimont et al. 2003). In addition, when there is a low gradient between the stream and riparian zones, flooding events and hyporheic flow can lead to input of salmon-derived

Accepted 9 June 2005 
nutrients (Ben-David et al. 1998, O'Keefe and Edwards 2003).

Mosses and liverworts comprise the dominant surface and ground cover throughout temperate rainforest ecosystems in the Pacific northwest. These constitute a minor contribution to overall biomass within forest ecosystems, yet are essential to nutrient dynamics, temperature regulation, and moisture retention of soils (Oechel and Van Cleve 1986). They occupy a significant portion of the landscape and use a variety of substrata such as humus, rock, woody debris, shrubs and standing trees (Jonsson 1997). Bryophytes lack true roots and absorb nutrients mainly throughout the leaf surface (Hébant 1977, Bates 1992). Typical sources of nutrients include atmospheric deposition (Soares and Pearson 1997, Williams et al. 1999, Aldous 2002), precipitation and canopy throughfall (Tamm 1953, Oechel and Van Cleve 1986, Eckstein 2000), litterfall decomposition (Oechel and Van Cleve 1986), underlying soils (Bates 1992), N-fixing symbioses (Deluca et al. 2002), as well as coarse woody debris and periodic flooding of stream terraces (Jonsson 1997). Bryophytes have efficient absorption (Weber and Van Cleve 1984, Oechel and Van Cleve 1986, Bates 1992) and extensive internal recycling (Rydin and Clymo 1989, Brown and Bates 1990, Wells and Brown 1996, Eckstein and Karlsson 1999, Eckstein 2000) and those occupying soil and humus substrata can act as autogenic ecosystem engineers (Jones et al. 1994).

In this study, we investigate the contribution of salmon-derived nitrogen to common moss and liverwort species at three representative watersheds on the central coast of British Columbia, Canada. Using nitrogen isotopes $\left(\delta^{15} \mathrm{~N}\right)$, we examine the extent of uptake of salmon-derived nitrogen in eight species of mosses and liverworts above and below waterfalls that are barriers to salmon migration. Within areas of high salmon transfer, we further assessed the nitrogen signature on wildlife trails and at salmon-carcass sites predicting that trails and feeding micro-sites act as major source pools of nitrogen in these riparian areas. Our findings build on previous studies at these watersheds that have investigated isotope signatures in invertebrate and vascular plant communities (Hocking and Reimchen 2002, Mathewson et al. 2003).

We also investigate variation in percent nitrogen in moss and liverworts across the gradient of salmonnutrient access, and use this as a potential proxy for productivity. Nitrogen is an essential macronutrient to all plants (Raven et al. 1992) and is generally considered to be the principal limiting nutrient in temperate forest ecosystems (Chabot and Mooney 1985, Chapin et al. 1986). Mosses and liverworts readily assimilate dissolved inorganic nitrogen, including $\mathrm{NO}_{3}^{-}$and $\mathrm{NH}_{4}^{+}$(Weber and Van Cleve 1981, Williams et al. 1999, Eckstein 2000). Variation in $\% \mathrm{~N}$ and $\delta^{15} \mathrm{~N}$ within and among species and habitats can provide insight into the contribution of Pacific salmon and its effect on productivity within the moss and liverwort community. Additionally, we examine community structure of these taxa across salmon nutrient gradients and compare richness, Shannon diversity and prevalence of nitrogen-rich versus nitrogen-poor soil indicators in multiple sites.

\section{Methods}

\section{Study site}

This study was conducted on three watersheds on the mid-coast of British Columbia, Canada: Clatse $\left(52^{\circ}\right.$ $\left.20.6^{\prime} \mathrm{N} ; 127^{\circ} 50.3^{\prime} \mathrm{W}\right)$, Ripley Bay $\left(52^{\circ} 25.5^{\prime} \mathrm{N} ; 127^{\circ}\right.$ $\left.53.1^{\prime} \mathrm{W}\right)$ and Neekas $\left(52^{\circ} 28.4^{\prime} \mathrm{N} ; 128^{\circ} 8.0^{\prime} \mathrm{W}\right)$. Most of our data is derived from Clatse. All watersheds occur on the mainland in the Coastal Western Hemlock Biogeoclimatic Zone, with a mean annual temperature of approximately $8^{\circ} \mathrm{C}$, and mean annual precipitation in excess of $4000 \mathrm{~mm}$ (Green and Klinka 1994). General site descriptions are given in several previous studies (Hocking and Reimchen 2002, Mathewson et al. 2003). Briefly, the riparian community is dominated by stands of western hemlock (Tsuga heterophylla), western red cedar, (Thuja plicata), amabilis fir (Abies amabilis), sitka spruce (Picea sitchensis) and red alder (Alnus rubra). Understory shrub species include false azalea (Menziesia ferruginea), Alaskan blueberry (Vaccinium alaskaense), oval-leaved blueberry ( $V$. ovalifolium), red huckleberry (V. parvifolium), devil's club (Oplopanax horridus), and salmonberry (Rubus spectabilis). Common herb layer species among all sites include false lily-of-the-valley (Maianthemum dilatatum), foamflower (Tiarella trifoliata), creeping raspberry (Rubus pedatus), dwarf dogwood (Cornus canadensis), deer fern (Blechnum spicant), lanky moss (Rhytidiadelphus loreus), step moss (Hylocomium splendens) and common green sphagnum (Sphagnum girgensohnii).

The Clatse and Neekas watersheds support autumn spawning populations of pink (Oncorhynchus gorbuscha) and chum (O. keta) salmon, with modest runs of coho (O. kisutch) and infrequent sockeye (O. nerka) (Manzon and Marshall 1981). Recent salmon returns average 17000 pink and 5000 chum salmon, and 18000 pink and 30000 chum salmon, on the Clatse and Neekas respectively (Dept of Fisheries and Oceans Escapement data: 1990-1999). Spawning occurs from late August to early November to the base of a five-meter waterfall one $\mathrm{km}$ upstream from the estuary on the Clatse and a tenmeter waterfall $2.1 \mathrm{~km}$ upstream on the Neekas. Bears (mainly Ursus americanus, but, occasional U. arctos) and wolves (Canis lupus) are active vectors of salmon carcasses. The Ripley Bay watershed serves as a control watershed due to the presence of a $20 \mathrm{~m}$ waterfall at the 
mouth of the river that prevents entrance by Pacific salmon to the stream.

\section{Experimental design}

In late June 2001, we examined moss and liverwort nitrogen nutrition and community structure from multiple habitat blocks on the Clatse and Ripley Bay rivers that differed in access to salmon nutrients. At Clatse River, we sampled from two blocks below the waterfall, 500-600 $\mathrm{m}$ upstream from the estuary, the first situated 5-20 $\mathrm{m}$ from the stream (CR-below/near), with access to salmon nutrients, and the second situated $90-110 \mathrm{~m}$ into the forest where there was minimal salmon transfer (CR-below/far). We also sampled two blocks above the waterfall, the first situated $200-250 \mathrm{~m}$ above the falls and 5-20 $\mathrm{m}$ from the stream (CR-above/near) and a second situated $350-400 \mathrm{~m}$ above the falls and $100-$ $120 \mathrm{~m}$ into the forest (CR- above/far). Although the waterfall prevents upstream movement of salmon, upstream movement of vertebrate predators may result in some nutrient transfer above the falls. These sampling sites coincide with habitat blocks used in previous studies in this watershed investigating isotope signatures in invertebrates (Hocking and Reimchen 2002) and vascular plant community structure (Mathewson et al. 2003), and were chosen based on similarity in forest structure, canopy cover and slope. We also sampled mosses and liverworts at the control watershed, Ripley Bay. Two habitats blocks were established 450-500 m upstream from the Ripley Bay estuary, the first situated 5-20 $\mathrm{m}$ from the stream (RB-near) and the second situated 100-120 $\mathrm{m}$ from the stream (RB-far). In total, six habitat blocks were established between these two watersheds.

For each habitat block, we designated three sequential $10 \times 10 \mathrm{~m}$ plots parallel to the stream. Within each plot, we sampled three $10 \times 1 \mathrm{~m}$ belt transects $(0 \mathrm{~m}, 5 \mathrm{~m}$ and $10 \mathrm{~m})$ perpendicular to the stream to collect representative specimens off the underlying humus layer for $\delta^{15} \mathrm{~N}$ and $\% \mathrm{~N}$ analysis. For each of the most common moss species, Rhytidiadelphus loreus, Hylocomium splendens and Sphagnum girgensohnii, one sample was taken on every transect in all habitat blocks $(n=9$ per species per habitat block). The only exception occurred in CRbelow/near, where $H$. splendens and $S$. girgensohnii were absent from one and two transects respectively $(\mathrm{n}=8$ and $\mathrm{n}=7$ ). The liverwort Pellia neesiana was also sampled but was less abundant in most plots. Four additional species, Rhizomnium glabrescens, Kindbergia oregana, Conocephalum conicum and Sphagnum squarrosum were collected on the Clatse River only. $R$. glabrescens and $K$. oregana were collected along transects in plots in the two habitat blocks below the falls (CR- below/near and CR- below/far), while C. conicum and S. squarrosum were collected in the two habitat blocks within $20 \mathrm{~m}$ of the stream above and below the falls (CR- below/near and CR- above/near). R. glabrescens typically occurred as epiphytic and was sampled off the underlying woody substratum. Sample sizes within blocks varied among species (range 4-9).

Due to the non-random distribution of salmon carcasses and nutrients in the riparian zone by vertebrate predators, we further investigated the micro-spatial influence of salmon nutrients on mosses and liverworts on the Clatse River. We compared $\delta^{15} \mathrm{~N}$ and $\% \mathrm{~N}$ values in the dominant moss $R$. loreus collected immediately adjacent to and $2 \mathrm{~m}$ away from wildlife trails and vertebrate feeding micro-sites. Two wildlife trail sections were chosen, one above and one below the falls. Trails were positioned roughly parallel to the stream at a distance that varied from 5-30 m. We made paired samples every $10 \mathrm{~m}$ along the wildlife trail from below and above the waterfalls ( $\mathrm{n}=13$ pairs below; $\mathrm{n}=12$ pairs above). At each site we sampled $R$. loreus from the edge of the trail as well as a second sample $2 \mathrm{~m}$ perpendicular off the trail towards the stream. We also sampled mosses adjacent to vertebrate feeding micro-sites below falls on the Clatse (CR- below/near). Feeding sites were identified by the presence of bony carcass remnants abandoned during the previous autumn spawning season. For each micro-site we took paired samples of $R$. loreus, one from directly on the site and a second from $2 \mathrm{~m}$ away in the downstream direction $(n=23$ pairs $)$.

Finally, we assessed moss community structure in all three plots within each habitat block from both watersheds. Belt transects within plots were reduced to line transects perpendicular to the stream $(0 \mathrm{~m}, 5 \mathrm{~m}$ and 10 $\mathrm{m})$, and \% cover of each moss and liverwort species along each transect was measured using the line intercept method (Bauer 1943). Percent cover is indicated as the fraction of each $10 \mathrm{~m}$ transect covered by a particular species. We used percent cover values found along transects to determine shifts in community structure corresponding to varying degrees of salmon transfer. We calculated species richness (S) using:

$\mathrm{S}=\Sigma \mathrm{s}_{\mathrm{n}}$

where $s$ is the number of species found on the $n$th transect. A Shannon index of diversity $\left(\mathrm{H}^{\prime}\right)$ was also calculated using:

$\mathrm{H}^{\prime}=-\left[\Sigma \mathrm{p}_{\mathrm{i}}\left(\ln \mathrm{p}_{\mathrm{i}}\right)\right]$

where $p_{i}$ is the relative abundance of the ith species on each transect within each habitat block.

We also investigated the proportionate representation of mosses and liverworts based on their soil-nitrogen indicator status according to Klinka et al. (1989) and Mathewson et al. (2003), to compare the percent cover of both nitrogen-poor and nitrogen-rich soil-indicator species among blocks. Plants can act as indicators of 
specific soil conditions from nutrient poor to rich soils, and may even prefer certain concentrations of a specific nutrient such as nitrogen, phosphorus, calcium or magnesium (Klinka et al. 1989). Although nutrient-rich and nutrient-poor indicators can co-occur, total cover of plants from different indicator categories within a defined area can provide insight into specific site properties within different biogeoclimatic subzones (Green and Klinka 1994).

In middle to late August 2000, a small number of collections were made from above and below the waterfall at Neekas River in plots that were used in previous studies on invertebrates and vascular plants from this watershed (Hocking and Reimchen 2002, Mathewson et al. 2003). Lanky moss (R. loreus) $(\mathrm{n}=4$ above falls, $\mathrm{n}=3$ below falls) and snake liverwort $(C$. conicum $)(\mathrm{n}=3$ above falls, $\mathrm{n}=4$ below falls) were collected at random within $15 \mathrm{~m}$ from the stream and within $200 \mathrm{~m}$ of either side of the waterfall.

\section{Isotope analysis}

All samples were oven-dried at $60^{\circ} \mathrm{C}$ for 7 days. We clipped the apical segments $(<1 \mathrm{~cm})$ of each moss sample, pulverized these in Wig-L-Bug grinder (Crescent Dental Co., Chicago, Illinois). Samples $(1 \mathrm{mg})$ were processed for continuous-flow isotope ratio mass spectrometry (CF-IRMS) analysis of nitrogen (Europa Scientific ANCA NT gas/solid/liquid preparation module coupled to a Europa Scientific Tracer/20 mass spectrometer). We follow the convention for isotopic characterization (Peterson and Fry 1987):

$\delta^{15} \mathrm{~N}(\%)=\left(\mathrm{R}_{\text {sample }} / \mathrm{R}_{\text {standard }}-1\right) \times 1000$

where $\mathbf{R}_{\text {sample }}$ is the ratio of the two isotopes of nitrogen $\left({ }^{15} \mathrm{~N} /{ }^{14} \mathrm{~N}\right)$ for any moss or liverwort sample and $\mathrm{R}_{\text {standard }}$ is the standard atmospheric ratio of ${ }^{15} \mathrm{~N} /{ }^{14} \mathrm{~N}(\mathrm{R}=$ $0.0036765 ; \delta^{15} \mathrm{~N}=0 \%$ ). In comparison, the $\delta^{15} \mathrm{~N}$ isotope signature of salmon tissue has been reported to range from $11.2 \%$ (Mathisen et al. 1988) to $13.01 \%$ (BenDavid et al. 1997).

\section{Statistical analyses}

We examined the effects of habitat block and plots within blocks on $\delta^{15} \mathrm{~N}$ and $\% \mathrm{~N}$ for each of the four common species (ANOVA's), and further evaluated the effect among blocks using Tukey's multiple comparison tests. In cases where variances were not equal we performed Dunnett's T3 tests of multiple comparisons. Individual sample sets of each habitat and species were tested for normality and all were normally distributed (one-sample Kolmogorov-Smirnov tests). For the less common species, including the small collection from the
Neekas River and those for comparisons between carcass micro-sites and wildlife trails, we compared $\delta^{15} \mathrm{~N}$ and $\% \mathrm{~N}$ using independent and paired t-tests (two-tailed). To examine the variance of $\delta^{15} \mathrm{~N}$ and $\% \mathrm{~N}$ among species, we used ANOVA and Tukey tests within a subset of available habitat blocks (Clatse- below/near; Clatse- above/near). The community structure data, including species richness (S), Shannon diversity $\left(H^{\prime}\right)$, and soil-nitrogen indicator status, were also analyzed using ANOVA and Tukey's multiple comparison tests. All statistical analyses were performed using SPSS (ver. 10, SPSS, Inc, Chicago, IL).

\section{Results \\ $\delta^{15} \mathbf{N}$ values}

There were major differences in the nitrogen signatures of mosses and liverworts among the sampling sites. In all of the four common species, $\delta^{15} \mathrm{~N}$ signatures varied significantly among habitat blocks on Clatse and Ripley: Rhytidiadelphus loreus $\left(\mathrm{F}_{5}=15.43, \mathrm{P}<0.001\right)$, Hylocomium splendens $\left(\mathrm{F}_{5}=5.78, \mathrm{P}<0.001\right)$, Sphagnum girgensohnii $\left(\mathrm{F}_{5}=4.40, \mathrm{P}=0.002\right)$, and Pellia neesiana $\left(\mathrm{F}_{4}=\right.$ $18.42, \mathrm{P}<0.001)$. The $\delta^{15} \mathrm{~N}$ signatures ranged from $2 \%$ to $7 \%$ higher below the falls near the salmon stream than at each of the other sites (Fig. 1). In all species there was a reduction in $\delta^{15} \mathrm{~N}$ with increased distance into the forest (significant for $R$. loreus and H. splendens), but this did not occur in riparian zones without salmon such as above the falls or at Ripley River. Signatures above the falls at Clatse River were not significantly different than at Ripley River where salmon were absent. For Kindbergia oregana and Rhizomnium glabrescens, which were only sampled on blocks below the falls at Clatse River, the former showed significantly higher values near the stream (mean diff. $=3.5 \%, \mathrm{t}_{13}=-2.38, \mathrm{P}=0.033$ ) while the latter showed no significant difference between sites (mean diff. $=0.5 \%, \mathrm{t}_{16}=-0.62, \mathrm{P}=0.54$ ). For Conocephalum conicum and Sphagnum squarrosum, which were only sampled on blocks near the stream at Clatse River, both showed significant increase in $\delta^{15} \mathrm{~N}$ below the falls compared to above falls $(C$. conicum mean diff. $=6 \%, \mathrm{t}_{8}=-3.29, \mathrm{P}=0.011 ; S$. squarrosum mean diff. $=4.5 \% ; \mathrm{t}_{10}=-4.68, \mathrm{P}=0.001$ ).

We also examined $\delta^{15} \mathrm{~N}$ signatures in Rhytidiadelphus loreus among feeding micro-sites and along wildlife trails on the Clatse River (Fig. 2). We observed a significant difference of $2.3 \%$ in $R$. loreus collected from feeding micro-sites relative to samples collected $2 \mathrm{~m}$ away $\left(\mathrm{t}_{22}=3.80, \mathrm{P}=0.001\right)$. The signatures for $R$. loreus on feeding micro-sites were higher than all other areas sampled, but were only marginally higher than samples collected at random from the same habitat block with high salmon transfer. 
Fig. 1. $\delta^{15} \mathrm{~N}$ isotope signatures in three common mosses ( $S$. girgensohnii, $R$. loreus, H. splendens) and one common liverwort (P. neesiana) from two watersheds on the central coast of British Columbia, Canada. Samples were collected on transects in six habitat blocks that vary in access to salmon nutrients. Habitat blocks consist of: CR-BN - Clatse River-below falls, near stream (highest salmon nutrient transfer); CR-BF - Clatse River-below falls, far from stream (minor salmon transfer); CR-AN Clatse River-above falls, near stream (within watershed control); CR-AF - Clatse River-above falls, far from stream (within watershed control); RB-N - Ripley Bay-near stream (control); RB-F - Ripley Bay, far from stream (control). Letters $(\mathrm{A}, \mathrm{B}, \mathrm{C})$ refer to homogeneous subsets derived from Tukey's multiple comparison tests.

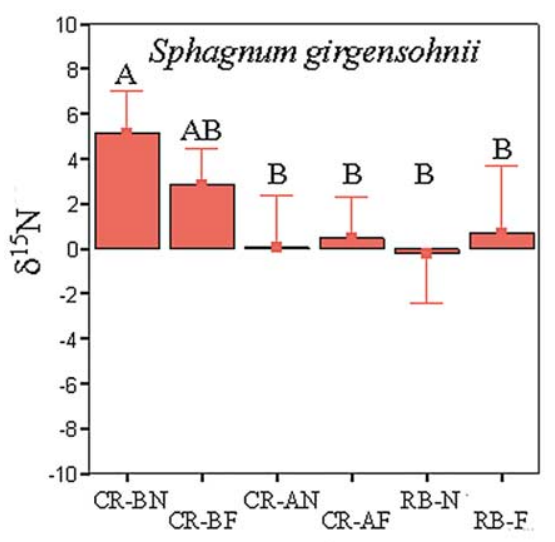

Habitat Block

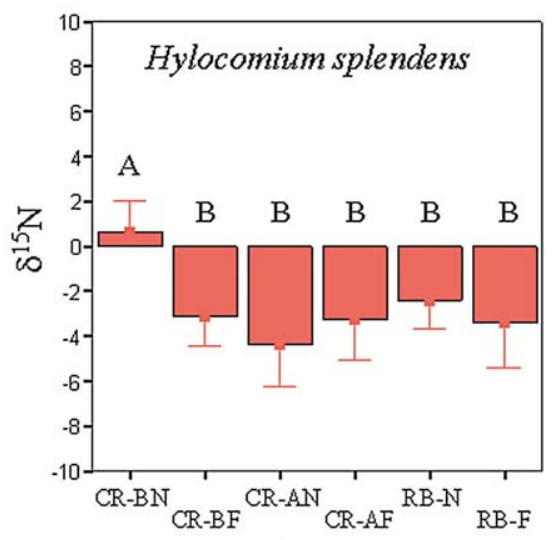

Habitat Block

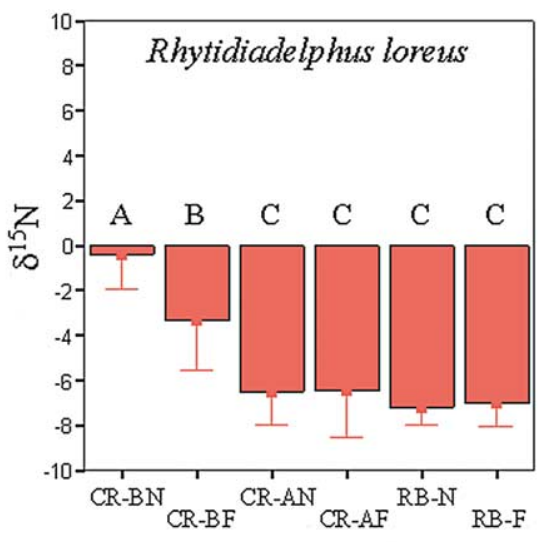

Habitat Block

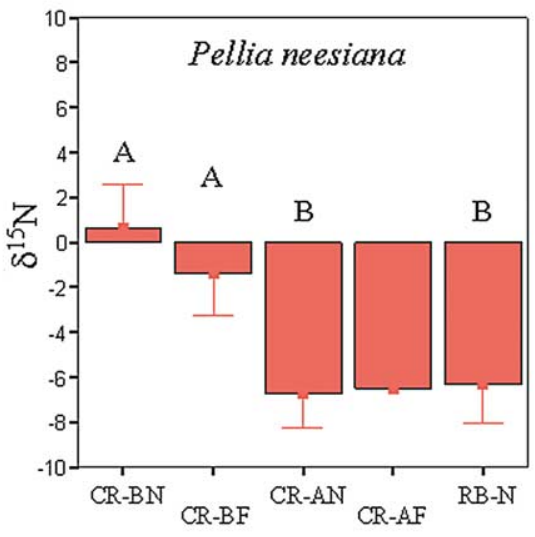

Habitat Block
For $R$. loreus collected below the falls on trails, there was a non-significant decrease of $1.5 \%$ between adjacent sites on and off the wildlife trail $\left(t_{12}=1.61, P=0.13\right)$ while above the falls, there was no effect (mean diff. $=$ $0.21 \%, \mathrm{t}_{11}=-0.31, \mathrm{P}=0.76$ ). $R$. loreus on trails below falls had higher signatures compared to those collected on trails above the falls (mean diff. $=3.55 \%, \mathrm{t}_{23}=4.40$, $\mathrm{P}<0.001$ ). Above the falls, the nitrogen signatures on and adjacent to the bear trails were both higher than $R$. loreus collected from sites distant from bear trails. However, this pattern was not observed below the falls, as $\delta^{15} \mathrm{~N}$ values from trails were similar or marginally lower than samples collected at random (Fig. 2).

Mosses and liverworts also differed in their $\delta^{15} \mathrm{~N}$ signatures within sites (Clatse- below/near: $\mathrm{F}_{7}=4.60$, $\mathrm{P}<0.001$; Clatse- above/near: $\mathrm{F}_{5}=12.11, \mathrm{P}<0.001$; Fig. 3). Sphagnum girgensohnii, and to a lesser extent $S$. squarrosum, had higher $\delta^{15} \mathrm{~N}$ signatures than all other species sampled. In the case of $S$. girgensohnii, this constituted a mean difference of $4.5 \%$ to $5.8 \%$ below the falls and $4.5 \%$ to $6.8 \%$ above the falls compared to the non- Sphagnum species.
On the Neekas River, we measured substantial enrichment in $\delta^{15} \mathrm{~N}$ in both species sampled below the falls compared to above the falls ( $R$. loreus: mean diff. $=$ $7.25 \%, \mathrm{t}_{5}=4.01, \mathrm{P}=0.01 ;$ C. conicum: mean diff. $=$ $5.08 \%, t_{5}=3.26, P=0.023$ ), supplementing the results observed along the spawning channel at Clatse.

\section{Percent nitrogen}

Percent $\mathrm{N}$ differed among species and among habitat blocks (Fig. 4). Significant differences were found in Rhytidiadelphus loreus, which had highest values below the falls near the stream $\left(\mathrm{F}_{5}=3.08, \mathrm{P}=0.017\right)$ and in Pellia neesiana, which had the highest values below the falls far from the stream $\left(\mathrm{F}_{4}=9.05, \mathrm{P}<0.001\right)$ but not in Hylocomium splendens $\left(\mathrm{F}_{5}=2.23, \mathrm{P}=0.066\right)$ or Sphagnum girgensohnii $\left(\mathrm{F}_{5}=1.53, \mathrm{P}=0.20\right)$. Below the falls, Rhizomnium glabrescens had significantly higher values in the block away from the stream $\left(\mathrm{t}_{16}=\right.$ 3.79, $\mathrm{P}=0.002$ ), but this did not occur for Kindbergia oregana $\left(\mathrm{t}_{13}=1.51, \mathrm{P}=0.16\right)$. The comparison of $\% \mathrm{~N}$ on near-stream blocks on either side of the falls at Clatse 


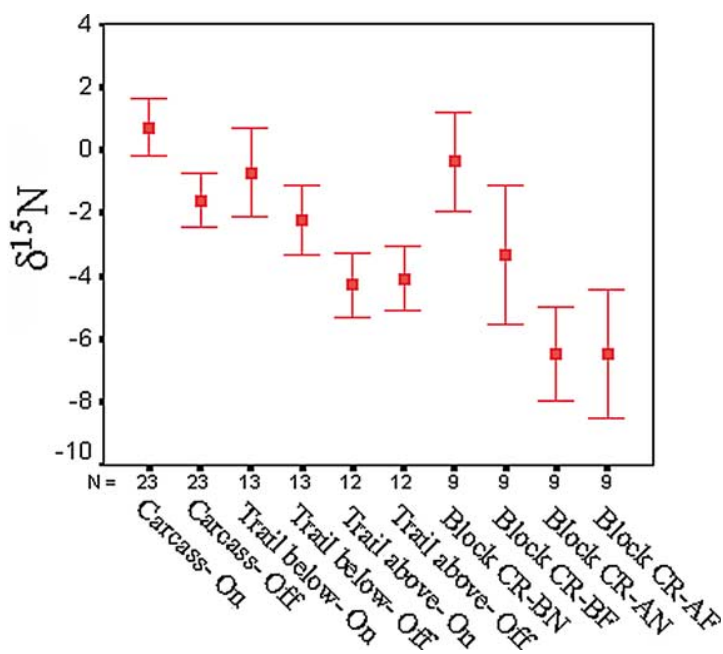

Fig. 2. $\delta^{15} \mathrm{~N}$ isotope signatures in the common moss Rhytidiadelphus loreus from multiple micro-sites on the Clatse River, on the central coast of British Columbia, Canada. Paired samples were taken immediately adjacent to and $2 \mathrm{~m}$ away from salmon carcass sites below the falls (carcass- on; carcass- off), and wildlife trails below and above the falls (trail below- on; trail below- off; trail above- on; trail above- off). For comparison, $\delta^{15} \mathrm{~N}$ signatures in $R$. loreus from the random collection in the four habitat blocks at Clatse are also shown (block BN; block BF; block AN; block AF; Fig. 1).

River did not show significant differences for either Conicephalum conicum $\left(\mathrm{t}_{8}=-1.04, \mathrm{P}=0.33\right)$ or Sphagnum squarrosum $\left(\mathrm{t}_{4.1}=-1.50, \mathrm{P}=0.21\right)$, though both exhibited marginally higher mean values along the salmon spawning channel.

For $R$. loreus, there were regular differences in $\% \mathrm{~N}$ among micro-sites (Fig. 5). At Clatse River below the falls, $\% \mathrm{~N}$ values on feeding micro-sites showed highly significant differences compared to those collected $2 \mathrm{~m}$ away $\left(\mathrm{t}_{22}=-4.38, \mathrm{P}<0.001\right)$. Similarly to $\delta^{15} \mathrm{~N}$, mean $\% \mathrm{~N}$ was highest on feeding micro-sites compared to any other areas sampled. $\% \mathrm{~N}$ on wildlife trails did not differ from adjacent sites $2 \mathrm{~m}$ off the trails above falls (mean diff. $=0.02 \%, \mathrm{t}_{11}=0.21, \mathrm{P}=0.84$ ) or below falls (mean diff. $\left.=0.01 \%, \mathrm{t}_{11}=-0.34, \mathrm{P}=0.91\right)$. However, there was a significant difference between samples collected on trails below and above the falls (mean diff. $=0.36 \%$, $\left.\mathrm{t}_{23}=4.46, \mathrm{P}<0.001\right)$. Overall, $\% \mathrm{~N}$ values were higher on trails and carcass micro-sites than samples collected at random from the same area, contrary to the pattern observed for $\delta^{15} \mathrm{~N}$ (Fig. 5).

Within each habitat block, \% $\mathrm{N}$ values varied among species and were highest in the liverworts $P$. neesiana and C. conicum compared to the mosses (Clatse- below/near: $\mathrm{F}_{7}=8.29, \mathrm{P}<0.001$; Clatse- above/near: $\mathrm{F}_{5}=22.62, \mathrm{P}<$ 0.001 ; Fig. 6). This constituted a mean difference varying from $0.5 \%$ to $1.2 \%$ depending on species and habitat block.

On the Neekas River, we observed higher $\% \mathrm{~N}$ values in both species below the falls compared to above the falls $\left(R\right.$. loreus: mean diff. $=0.61 \%, \mathrm{t}_{5}=4.73, \mathrm{P}=0.005$; C. conicum : mean diff. $=0.43, \mathrm{t}_{5}=3.83, \mathrm{P}=0.012$ ).

\section{Community structure}

Overall, the most dominant species in all habitat blocks was $R$. loreus, followed by $H$. splendens and $S$. girgensohnii, which dominated in moist nutrient poor areas such as Ripley Bay and Clatse above the falls (Fig. 7). On Clatse below the falls close to the stream, where there was highest access to salmon nutrients, we observed the most number of species. This included increased coverage of the liverworts $C$. conicum and P. neesiana, which are nitrogen- and calcium-rich soil-indicators.

Moss and liverwort community structure differed among habitats. Species richness (S) was highest in the block below the falls, near the stream on Clatse (CRbelow/near) and the lowest in the block far from the stream on Ripley (RB-far) (ANOVA: $\mathrm{F}_{5}=25.35, \mathrm{P}<$ 0.001 ; Fig. 8). The Shannon diversity index $\left(\mathrm{H}^{\prime}\right)$ was also highest below falls, near the stream on the Clatse, but did not differ from the other sites close to stream on
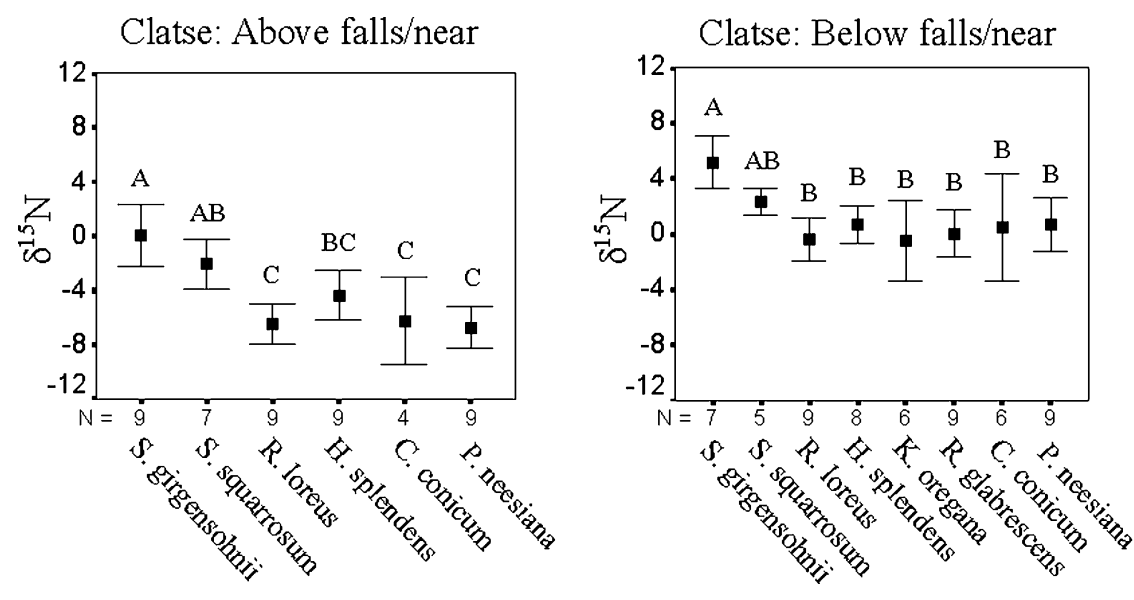

Fig. 3. $\delta^{15} \mathrm{~N}$ isotope signatures in all moss and liverwort species collected from two representative habitat blocks on the Clatse River, on the central coast of British Columbia, Canada. Letters (A, B, C) refer to homogeneous subsets derived from Tukey's multiple comparison tests. 
Fig. 4. Foliar percent $\mathrm{N}$ in three common mosses ( $S$. girgensohnii, $R$. loreus, $H$. splendens) and one common liverwort

(P. neesiana) from two watersheds on the central coast of British Columbia, Canada. Samples were collected on transects in six habitat blocks that vary in access to salmon nutrients. Habitat blocks consist of: CR-BN - Clatse

River-below falls, near stream (highest salmon nutrient transfer); CR-BF Clatse River-below falls, far from stream (minor salmon transfer); CR-AN - Clatse River-above falls, near stream (within watershed control); CR-AF - Clatse River-above falls, far from stream (within watershed control); RB-N - Ripley Bay-near stream (control); RB-F - Ripley Bay, far from stream (control). Letters (A, B) refer to homogeneous subsets derived from Tukey's multiple comparison tests.
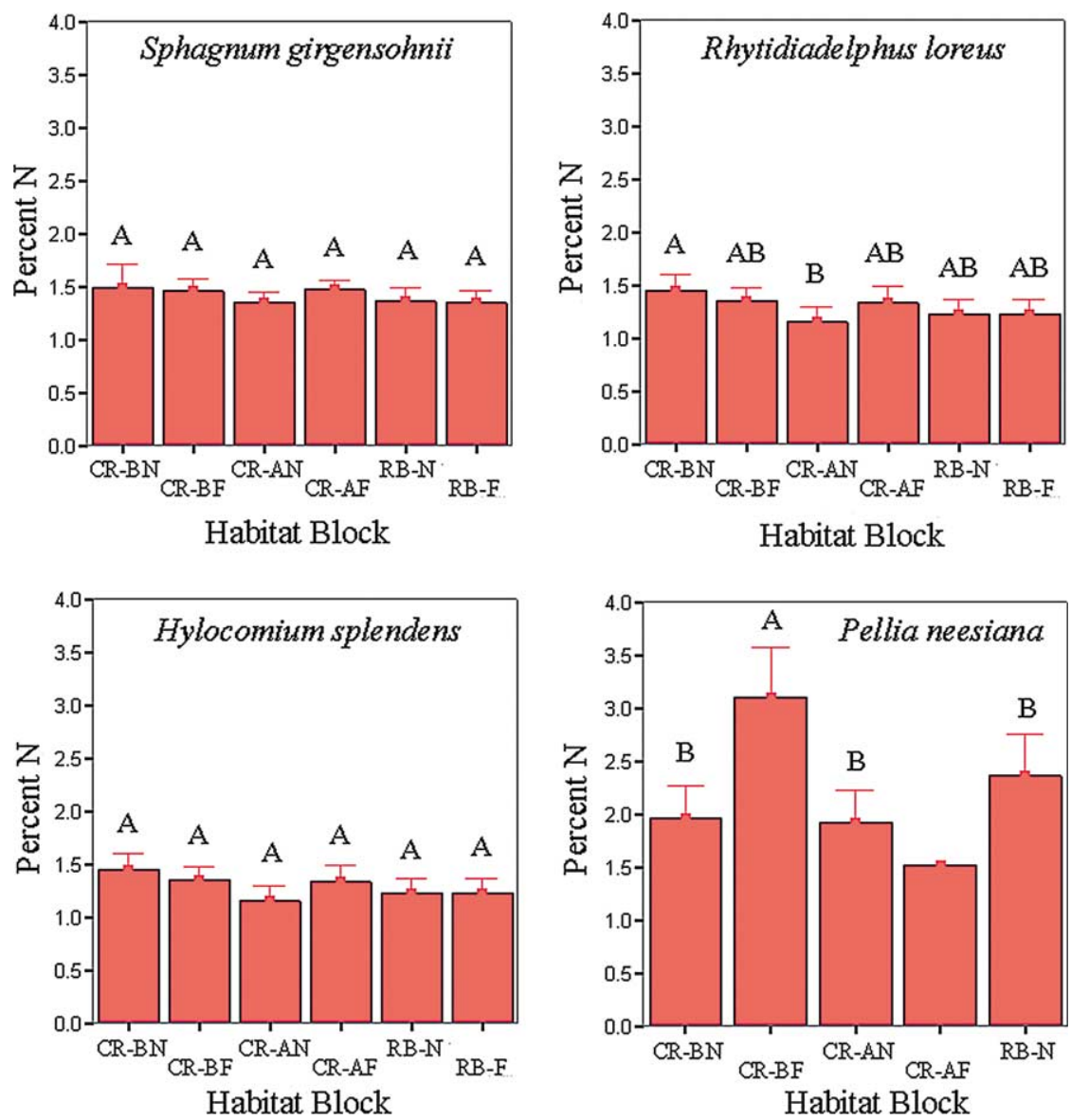

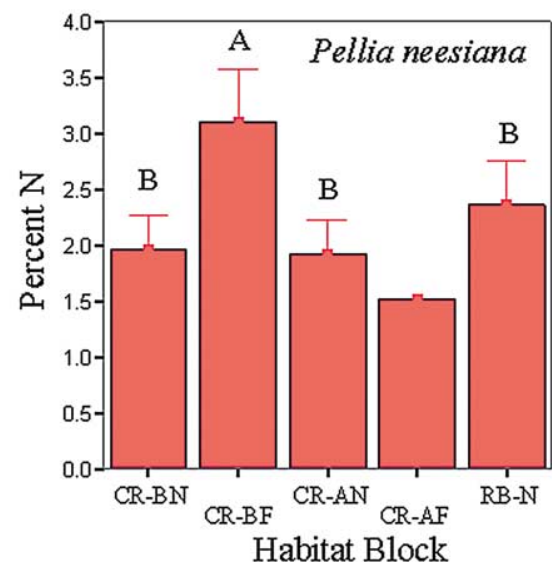

Ripley and Clatse above the falls (ANOVA: $\mathrm{F}_{5}=7.17$, $\mathrm{P}<0.001$; Fig. 8). Mean percent cover of $\mathrm{N}$-rich soilindicator species on the Clatse-below/near was $8 \%$ higher than below/far at Clatse and at least $11 \%$ higher than all other blocks $\left(\mathrm{F}_{5}=6.58, \mathrm{P}<0.001\right.$; Fig. 9). In comparison, percent cover of $\mathrm{N}$-poor soil-indicator species varied from $12 \%$ to $35 \%$ lower below/near at Clatse compared to all other blocks $\left(\mathrm{F}_{5}=7.21, \mathrm{P}<\right.$ 0.001; Fig. 9).

\section{Discussion}

\section{$\delta^{15} \mathrm{~N}$ values}

Our results indicate that mosses and liverworts, which comprise the dominant ground cover in temperate forests of the Pacific northwest, exhibit substantive uptake of salmon-derived nitrogen primarily extending from predator foraging activity on Oncorhynchus spp. We observe enrichment of $2 \%$ to $7 \%$ in $\delta^{15} \mathrm{~N}$ in all common species collected on transects $0-20 \mathrm{~m}$ from the Clatse River spawning channel compared to all other habitat blocks on the same watershed and two blocks on an adjacent control watershed. The pattern of $\delta^{15} \mathrm{~N}$ signatures across habitat blocks is consistent among the seven humus-dwelling species sampled, and concordant with the diverse assemblage of taxa that demonstrate uptake of salmon nutrients by primary and secondary consumers (Bilby et al. 1996, Ben-David et al. 1998, Cederholm et al. 2000, Naiman et al. 2002, Gende et al. 2002, Hocking and Reimchen 2002, Reimchen et al. 2003). Our analyses of isotopic signatures in mosses above and below waterfalls, which acts as a sharp ecological gradient of salmon density, often demonstrated larger differences between sites than over equivalent distances within the riparian zone perpendicular to the stream. This indicates that the signature of salmon can be detected in mosses and liverworts to distances of $100 \mathrm{~m}$ into the riparian zone, a pattern that has been observed previously in vascular plants and invertebrates (Ben-David et al. 1998, Hilderbrand et al. 1999, Hocking and Reimchen 2002). The observed $\delta^{15} \mathrm{~N}$ enrichment in lanky moss $(R$. loreus) and snake liverwort $(C$. conicum) collected adjacent to the spawning channel at the Neekas River supplements the results observed at Clatse and suggests that this pattern may be wide- 


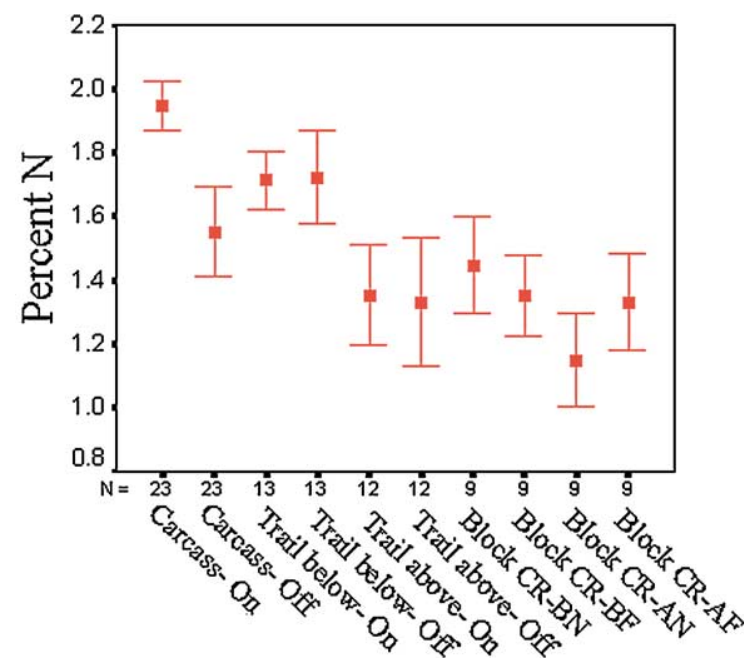

Fig. 5. Foliar percent $\mathrm{N}$ in the common moss Rhytidiadelphus loreus from multiple micro-sites on the Clatse River, on the central coast of British Columbia, Canada. Paired samples were taken immediately adjacent to and $2 \mathrm{~m}$ away from salmon carcass sites below the falls (carcass- on; carcass- off), and wildlife trails below and above the falls (trail below- on; trail below- off; trail above- on; trail above- off). For comparison, $\delta^{15} \mathrm{~N}$ signatures in $R$. loreus from the random collection in the four habitat blocks at Clatse are also shown (block BN; block BF; block AN; block AF; Fig. 4).

spread along salmon streams throughout the Pacific Northwest.

The only exception to the trend of reduced $\delta^{15} \mathrm{~N}$ signatures with increased distance from the spawning region on Clatse was observed in $R$. glabrescens, the only species collected directly off a woody substratum. Since all other species were collected from the humus layer, this may suggest that salmon-derived nitrogen is not as accessible to epiphytic species, and is only available via $\mathrm{N}$ in humus. Epiphytic mosses have a high capacity to absorb atmospheric $\mathrm{NO}_{3}^{-}$and $\mathrm{NH}_{4}^{+}$(Clark et al. 1998, Hietz et al. 2002), and may not access the limited total nitrogen from decaying wood, which itself may also be enriched in salmon nitrogen (Reimchen et al. 2003). However, high fractionation during ammonia volatilization from the abundant decaying salmon carcasses in the stream channel and in the forest could lead to a depleted atmospheric $\mathrm{N}$ source for $R$. glabrescens (Robinson 2001) throughout the riparian zone. As a consequence, we cannot exclude salmon-derived atmospheric $\mathrm{N}$ as a partial source for $R$. glabrescens within $100 \mathrm{~m}$ from the stream given the absence in our data of a completely non-salmon comparison for this species.

For lowland and mid-elevation rainforest ecosystems of coastal British Columbia, Rhytidiadelphus loreus is often the dominant ground cover (Pojar and MacKinnon 1994). Our data on isotopic signatures in this species demonstrated high localized spatial heterogeneity concordant with the distribution of salmon carcasses abandoned by bears and wolves (Reimchen 1994, 2000, Darimont et al. 2003), and to a lesser extent, associated with the use of trails established by wildlife. Hilderbrand et al. (1999) report $96 \%$ of the salmonderived $\mathrm{N}$ consumed by adult female brown bears is excreted as urine and 3\% excreted as faeces, much of which is distributed along trails. Because urine is depleted in $\delta^{15} \mathrm{~N}$ relative to diet (Gannes et al. 1997), this may partly explain why $\delta^{15} \mathrm{~N}$ gradients off trails are not as pronounced as off carcass sites. It is also likely that fractionation from ammonia volatilization from decaying salmon carcasses results in a very locally enriched signature of $\mathrm{NH}_{4}^{+}$(Cocks et al. 1998) compared to more evenly distributed signatures along trails. Enrichment in $R$. loreus along trails compared to random transects was particularly evident above the falls at Clatse, demonstrating the importance of trails as vectors of salmon-derived $\mathrm{N}$ over longer distances. Overall, the combination of carcass deposition by predators and trail corridor use by bears and other wildlife enhances the external nitrogen source pools on the forest floor and creates a non-uniform and clumped distribution of nutrients. Such a heterogeneous nutrient
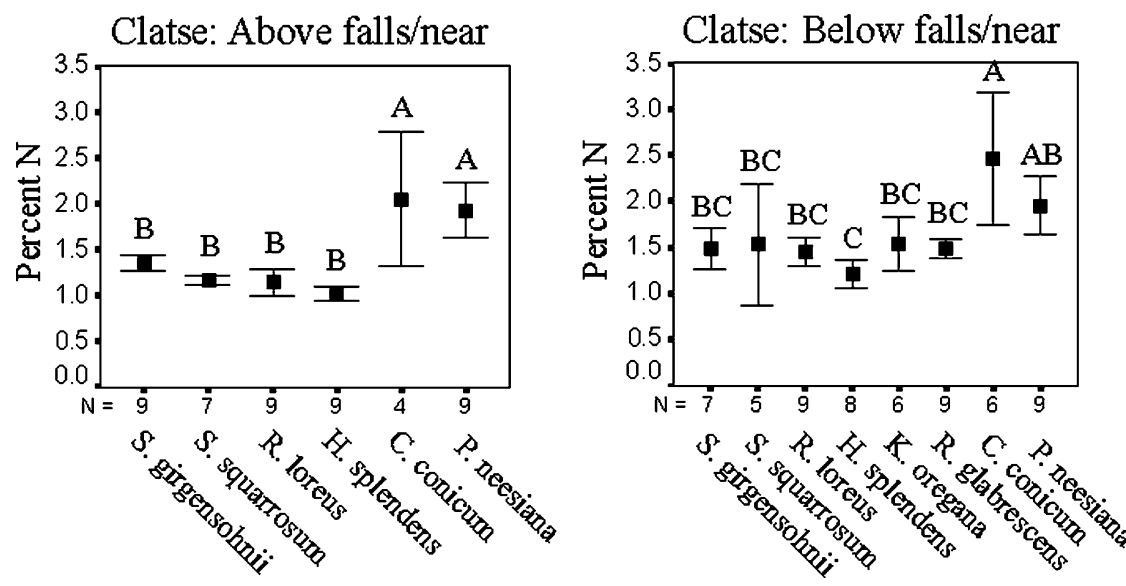

Fig. 6. Foliar percent $\mathrm{N}$ in all moss and liverwort species collected from two representative habitat blocks on the Clatse River, on the central coast of British Columbia, Canada. Letters (A, B, C) refer to homogeneous subsets derived from Tukey's multiple comparison tests. 
Clatse River: Below-near

Other

Poly. juniperinum

Polytrichium commune

Kindbergia praelonga

Plagio. undulatum

Conic. conicum

Kindbergia oregana

S.squarrosurn

R. glabrescens

Pellia neesiana

H. splendens

S. girgensohnii

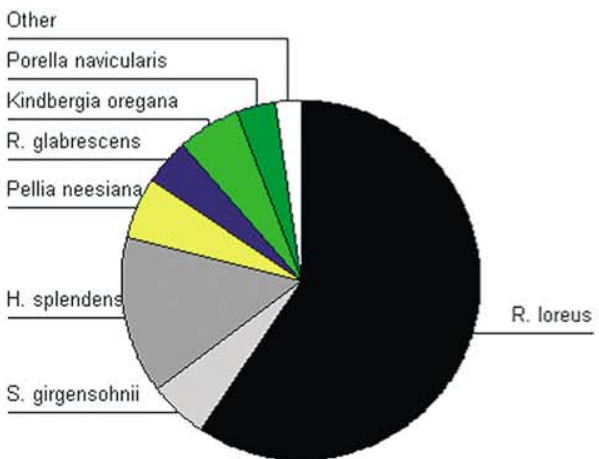

Clatse River: Above-near

Other

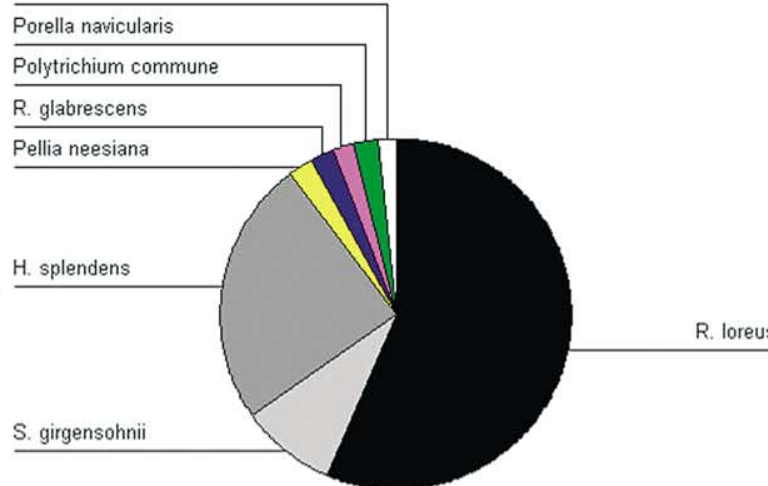

Clatse River: Above-far

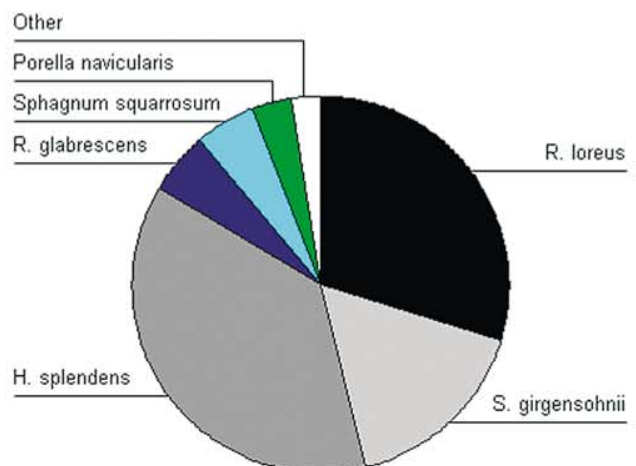

Ripley Bay River: Near

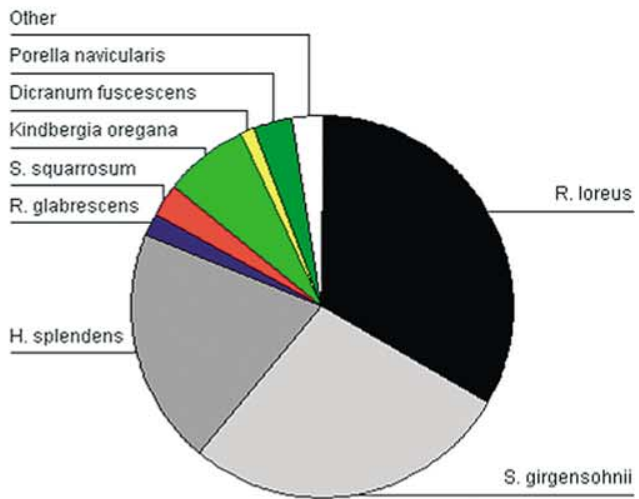

Ripley Bay River: Far

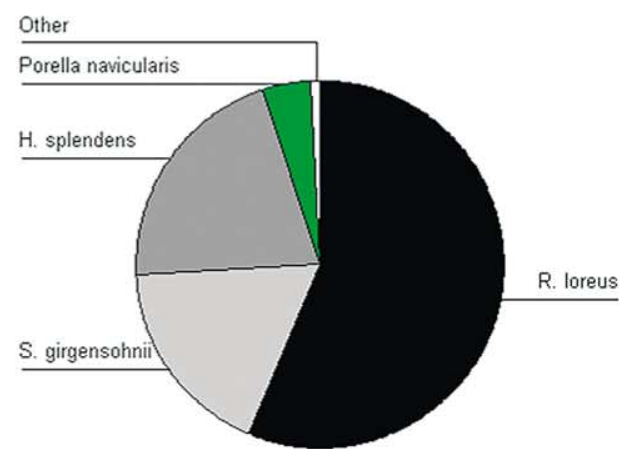

Fig. 7. Mean percent cover of all moss and liverwort species in six habitat blocks on the Clatse and Ripley Bay watersheds that vary in access to salmon nutrients, on the central coast of British Columbia, Canada. Habitat block 'Clatse River-below-near' is immediately adjacent to the salmon spawning channel with highest access to salmon nutrients, followed by 'Clatse River-below-far'. Other sites are control sites with little to no salmon nutrient input. Species of less than $1 \%$ total cover were summed and placed in the category 'other'. 

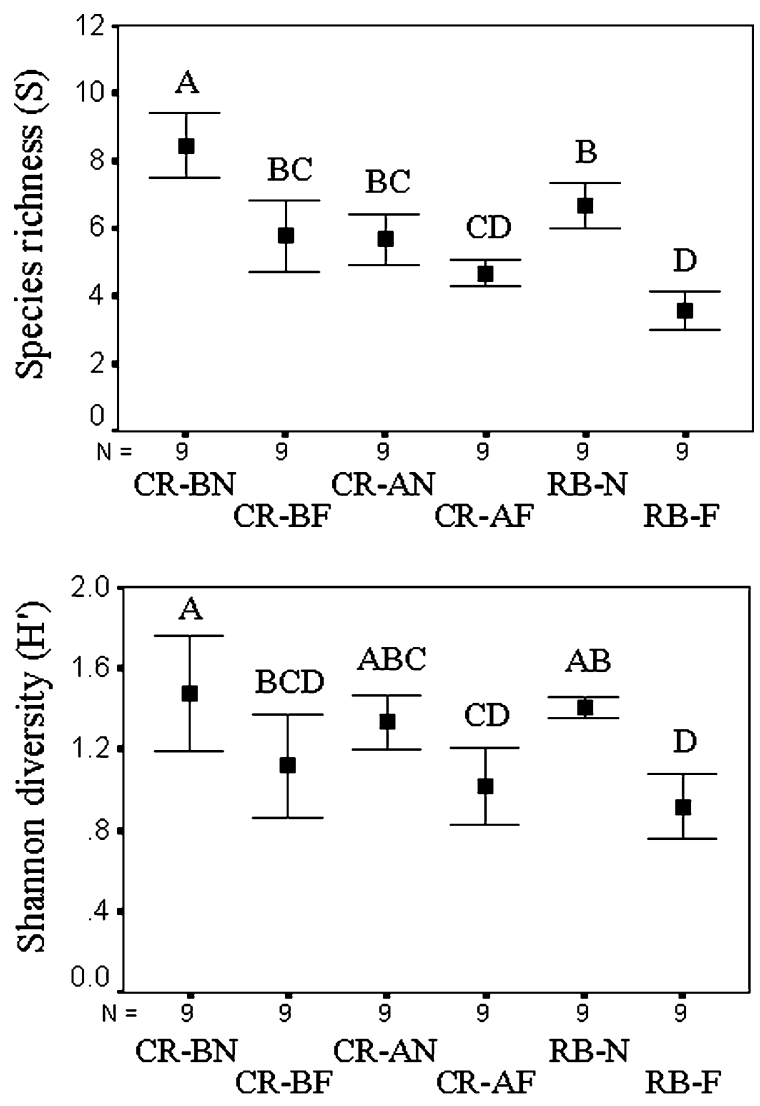

\section{Habitat Block}

Fig. 8. Species richness $(\mathrm{S})$ and Shannon diversity $\left(\mathrm{H}^{\prime}\right)$ of the moss and liverwort community in six habitat blocks on the Clatse and Ripley Bay watersheds that vary in access to salmon nutrients, on the central coast of British Columbia, Canada. Habitat block 'Clatse River-below-near' is immediately adjacent to the salmon spawning channel with highest access to salmon nutrients, followed by 'Clatse River-below-far'. Other sites are control sites with little to no salmon nutrient input. Letters (A, B, C, D) refer to homogeneous subsets derived from Tukey's multiple comparison tests.

distribution may have implications for niche partitioning among bryophyte species.

$\delta^{15} \mathrm{~N}$ signatures varied among moss and liverwort species, with the highest signatures observed in Sphagnum spp, particularly $S$. girgensohnii. Variation in $\delta^{15} \mathrm{~N}$ signatures in vascular plants within habitats is often attributed to differences in the predominant $\mathrm{N}$ source $\left(\mathrm{NH}_{4}^{+}, \mathrm{NO}_{3}^{-}\right.$, organic $\mathrm{N}$, or fixed $\left.\mathrm{N}\right)$, differences in fractionation during $\mathrm{N}$ uptake, and variable plantmycorrhizal interactions (Nadelhoffer and Fry 1994, Schulze et al. 1994, Michelsen et al. 1998, Hobbie et al. 2000, Evans 2001). Species in nutrient poor habitats are often more depleted in foliar $\delta^{15} \mathrm{~N}$ than species found in nutrient rich habitats (Hobbie et al. 2000, Mathewson et al. 2003), yet we observe in bryophytes an opposite pattern with high signatures in the nutrient-poor Sphag- num spp. and relatively low signatures in the nutrientrich liverworts. Hyaline cells in Sphagnum are known to exhibit high retention of water and surplus nutrients (Daniels and Eddy 1990), and as a result leave the surrounding water nutrient-depleted (Anderson and Ammann 1991). Nitrogen losses from these cells may be highly fractionated leaving foliar tissue comparatively enriched. Other possibilities include $\mathrm{N}$-fixing symbioses such as that observed in mosses of the boreal forest (Deluca et al. 2002), or partitioning of the nitrogen niche (ie-N source) among moss and liverwort species. Sphagnum assimilates $\mathrm{NO}_{3}^{-}$and $\mathrm{NH}_{4}^{+}$, with no preference being displayed between these two forms (Williams et al. 1999). In comparison, recent studies on mosses in heath ecosystems reveal the importance of organic $\mathrm{N}$ from free amino acids to nitrogen budget of multiple species (Kielland 1997, Michelsen et al. 1998, Näsholm et al. 1998). The inter-specific pattern of $\delta^{15} \mathrm{~N}$ signatures among mosses and liverworts from our data remains very similar in all habitat blocks despite an upwards shift of $\sim 5 \%$ below the falls on Clatse in all species, and suggests that many forms of nitrogen may be enriched in salmon $\mathrm{N}$ along the spawning channel.

\section{Percent nitrogen}

Temperate rainforests subject to the annual pulse of salmon nutrients show elevated foliar percent $\mathrm{N}$ in vascular plant communities (Helfield and Naiman 2001, Naiman et al. 2002, Mathewson et al. 2003), which suggests enhanced primary productivity in riparian zones with access to salmon-derived nitrogen. Our data show some instances of increased $\% \mathrm{~N}$ in mosses and liverworts collected at random along salmon streams compared to other sites, particularly on the Neekas River, though many comparisons revealed similar values between salmon and non-salmon habitats. The most striking pattern we observe is high $\% \mathrm{~N}$ values for the most abundant moss $R$. loreus among carcass feeding sites, followed by samples along wildlife trails, in comparison to samples collected from the transects below the falls at Clatse. These data are consistent with the importance of carcass transfer and excretion by secondary consumers as sources of salmon-derived nitrogen within habitats adjacent to spawning beds and indicate the coarse grain or patchiness of the nutrient pools within these habitats. The variability in $\% \mathrm{~N}$ among carcass sites, trails and the random collection within the Clatse-below/near habitat exceeded that of the $\delta^{15} \mathrm{~N}$ signatures themselves indicating the degree of competition for available nitrogen among non-vascular and vascular plants in these temperate rainforests. Furthermore, these data demonstrate the widespread enrichment in $\delta^{15} \mathrm{~N}$ throughout this riparian zone 


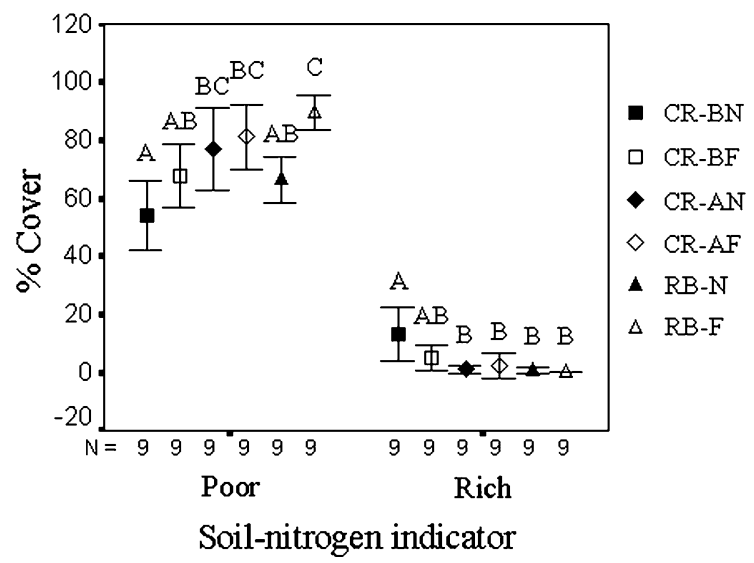

Fig. 9. Percent cover of nitrogen-rich and nitrogen-poor soil indicator species (based on Klinka et al. 1989) in six habitat blocks on the Clatse and Ripley Bay watersheds that vary in access to salmon nutrients, on the central coast of British Columbia, Canada. Habitat block 'Clatse River-below-near' is immediately adjacent to the salmon spawning channel with highest access to salmon nutrients, followed by 'Clatse Riverbelow-far'. Other sites are control sites with little to no salmon nutrient input. Letters (A, B, C) refer to homogeneous subsets derived from Tukey's multiple comparison tests.

(Hocking and Reimchen 2002, Mathewson et al. 2003), which presumably reflects thousands of years of the salmon-bear-forest association. Overall, increased foliar $\mathrm{N}$ concentrations are correlated to increased rates of photosynthesis and higher turnover (Reich et al. 1997, Hikosaka and Hirose 2000), and areas with high salmon carcass transfer and/or high wildlife activity may promote increased primary productivity of the moss layer.

Plants with higher foliar concentrations of a particular nutrient may be more competitive for that specific nutrient (Mamolos and Veresoglou 2000). In riparian zones of the Pacific northwest, vascular plants that indicate nitrogen-rich soil conditions tend to have higher foliar $\% \mathrm{~N}$ than nitrogen-poor soil indicators, and are more prevalent along salmon spawning channels of the Clatse and Neekas rivers (Mathewson et al. 2003). This pattern is also shown in the current study, as was evident in the high $\% \mathrm{~N}$ values in the liverwort species $P$. neesiana and $C$. conicum in all habitat blocks and lower values in the remaining moss species that we investigated, which are nitrogen-poor indicators (Klinka et al. 1989). This is consistent with previous evidence of elevated nitrogen levels in thallose liverworts (Shaw and Goffinet 2000) and suggests that these liverworts may have increased competitive ability in nutrient-rich habitats along salmon streams.

\section{Community response}

Among mosses and liverworts, we observed greater species richness and increased prevalence of nitrogenrich soil indicators on transects along the spawning channel at Clatse compared to all other habitat blocks. Comparisons with the Shannon diversity index also demonstrated highest mean values in this region although the trends were more marginal, reflecting increased evenness as a component to the diversity index. Our results are concordant with global patterns of richness and productivity in vascular plants (Currie 1991).

The increased richness observed below/near on Clatse occurred partly due to the increased prevalence of nitrogen-rich soil indicators including the liverworts $P$. neesiana and C. conicum (Klinka et al. 1989). Rich-soil indicator plants occur in soils that have six times the mineralizable nitrogen, double the total soil $\mathrm{N}$, and available $\mathrm{Ca}, \mathrm{Mg}$ and $\mathrm{K}$ than soils dominated by poorsoil indicators, and occur in areas with reduced forest floor $\mathrm{pH}$ and $\mathrm{C} / \mathrm{N}$ ratios (Klinka et al. 1989). C. conicum was only evident on transects of the salmon-bearing watershed, and was dramatically reduced above the falls. As well, P. neesiana was evident in far higher abundance below the falls on Clatse, indicating that thallose liverworts interspersed with mosses in the humus substratum may be exploiting a unique niche available through wildlife activity and transfer of salmon carcasses. The spatial heterogeneity of both $\delta^{15} \mathrm{~N}$ signatures and $\% \mathrm{~N}$ among species and microhabitats likely reflects a variety of localized nutrient source pools and a coarsegrained distribution of available niches. Although we emphasize nitrogen as a predictor for community diversity, other nutrients such as calcium, phosphorus and magnesium may be equally important in determining community structure. This may be particularly true for the liverworts C. conicum and P. neesiana, which are indicators of calcium-rich soils. Overall, salmon-rich habitats display the greatest variation among transects in presence and percent coverage of nitrogen indicator species, suggesting that increased community richness and niche partitioning among mosses and liverworts is an outcome of increased nutrient heterogeneity (McKane et al. 2002).

\section{Implications on nutrient dynamics in temperate forest ecosystems}

The flow of salmon-derived nutrients through riparian ecosystems comprises multiple levels, from initial transfer from streams to the forest floor through surface layers, to soils, to root systems of the vascular plant community and through successive higher trophic levels. The moss and liverwort layer on the forest floor has ecosystem-level effects as these regulate soil temperature and retain soil moisture levels (Oechel and Van Cleve 1986). Additionally, bryophytes are known to be effective competitors with vascular plants for incoming nutrients (Oechel and Van Cleve 1986). Weber and Van 
Cleve (1981) have shown that bryophyte layers including Hylocomium splendens effectively capture over $90 \%$ of dissolved N. Efficient nutrient uptake, recycling and slow decomposition rates may allow the bryophyte layer to control nutrient availability to vascular plants, and potentially act as an autogenic ecosystem engineer (Jones et al. 1994). This may contribute to the observations of enhanced primary productivity in vascular plants where salmon-derived nutrients are available (Helfield and Naiman 2001, Naiman et al. 2002, Mathewson et al. 2003).

\section{Conclusion}

Assessment of $\delta^{15} \mathrm{~N}$, percent $\mathrm{N}$ and community structure in mosses and liverworts among multiple habitat blocks in coastal temperate rainforests of British Columbia provides strong evidence for a community wide response to marine-derived nutrients provided by Pacific salmon spawning events. Rhytidiadelphus loreus, the most abundant moss species, exhibits elevated nitrogen levels on bear trails and feeding-micro-sites where salmon nutrients are available and suggests coarse-grained distribution of nutrient source pools. Such spatial heterogeneity of nutrient availability may provide a broader range of niches that consequently enhances biodiversity in such habitats. Our data provide further evidence for the major contribution of salmon-derived nutrients to terrestrial ecosystems in watersheds of the North Pacific (Willson et al. 1998, Stockner 2003).

Acknowledgements - Thanks to the David Suzuki Foundation and NSERC IPS (to MDH) for financial support of the salmonforest project. We are grateful to the Heiltsuk First Nations, Robert Johnson, Mike Windsor, Dan Windsor, Buddy Windsor, Chester Starr, Larry Jorgensen, Dr. Bristol Foster, Chris Darimont and the Raincoast Conservation Society for field assistance and local project support. Thanks also to Carsten Brinkmeier for assistance in the early stages of the project, Myles Stocki for isotope analyses (Univ. of Saskatchewan), Dr. Jim Pojar for discussion and Dr. Barbara Hawkins and Dr. Richard Ring for additional laboratory space.

\section{References}

Aldous, A. R. 2002. Nitrogen retention by Sphagnum mosses: responses to atmospheric nitrogen deposition and drought. - Can. J. Bot. 80: 721-731.

Anderson, L. E. and Ammann, K. 1991. Cell wall ornamentation in the hyaline cells of Sphagnum. - J. Hattori Bot. Lab. 69: 49-64.

Bates, J. W. 1992. Mineral nutrient acquisition and retention by bryophytes. - J. Bryol. 17: 223-240.

Bauer, H. L. 1943. The statistical analysis of chaparral and other plant communities by means of transect samples. - Ecology 24: 45-60.

Ben-David, M., Bowyer, R. T., Duffy, L. K. et al. 1997. Social behaviour and ecosystem processes: river otter latrines and nutrient dynamics of terrestrial vegetation. - Ecology 79: 2567-2571.
Ben-David, M., Hanley, T. A. and Schell, D. M. 1998. Fertilization of terrestrial vegetation by spawning Pacific salmon: the role of flooding and predator activity. - Oikos 83: $47-55$.

Bilby, R. E., Fransen, B. R. and Bisson, P. A. 1996. Incorporation of nitrogen and carbon from spawning coho salmon into the trophic system of small streams: evidence from stable isotopes. - Can. J. Fish. Aquat. Sci. 55: 19091918.

Brown, D. H. and Bates, J. W. 1990. Bryophytes and nutrient cycling. - Bot. J. Linn. Soc. 104: 129-147.

Cederholm, C. J., Johnson, D. H., Bilby, R. E. et al. 2000. Pacific salmon and wildlife-ecological contexts, relationships and implications for management. - Special Edn Tech. Rep., Prepared for D. H. Johnson and T. A. O'Neil, Wildlife-Habitat Relationships in Oregon and Washington. Washington Dept of Fish and Wildlife, Olympia, Washington.

Chabot, B. F. and Mooney, H. A. 1985. Physiological ecology of North American plant communities. - Chapman and Hall.

Chaloner, D. T., Martin, K. M., Wipfli, M. S. et al. 2002. Marine carbon and nitrogen in southeastern Alaska food webs: evidence from artificial and natural streams. - Can. J. Fish. Aquat. Sci. 59: 1257-1265.

Chapin, F. S. III, Vitousek, P. M. and Van Cleve, K. 1986. The nature of nutrient limitation in plant communities. - Am. Nat. 127: $48-58$.

Clark, K. L., Nadkarni, N. M., Schaefer, D. et al. 1998. Atmospheric deposition and net retention of ions by the canopy in a tropical montane forest, Monteverde, Costa Rica. - J. Trop. Ecol. 14: 27-45.

Cocks, M. P., Balfour, D. A. and Stock, W. D. 1998. On the uptake of ornithogenic products by plants on the island mountains of Dronning Maud Land, Antarctica, using stable isotopes. - Polar Biol. 20: 107-111.

Currie, D. J. 1991. Energy and large-scale patterns of animal species and plant species richness. - Am. Nat. 137: $27-$ 49.

Daniels, R. E. and Eddy, A. 1990. Handbook of European Sphagna. - Inst. of Terrestrial Ecology. Huntingdon, England.

Darimont, C. T., Reimchen, T. E. and Paquet, P. C. 2003. Foraging behaviour by gray wolves on salmon streams in coastal British Columbia. - Can. J. Zool. 81: 349-353.

Deluca, T. H., Zackrisson, O., Nilsson, M-C. et al. 2002. Quantifying nitrogen-fixation in feather moss carpets of boreal forests. - Nature 419: 917-920.

Eckstein, R. L. 2000. Nitrogen retention by Hylocomium splendens in a subarctic birch woodland. - J. Ecol. 88: 506-515.

Eckstein, R. L. and Karlsson, P. S. 1999. Recycling of nitrogen among segments of Hylocomium splendens as compared with Polytrichium commune: implications for clonal integration in an ectohydric bryophyte. - Oikos 86: 87-96.

Evans, D. R. 2001. Physiological mechanisms influencing plant nitrogen isotope composition. - Trends Plant Sci. 6: $121-$ 127.

Gannes, L. Z., O'Brien, D. M. and Martinez del Rio, C. 1997. Stable isotopes in animal ecology: assumptions, caveats and a call for more laboratory experiments. - Ecology 78: 1271 1276.

Gende, S. M., Edwards, R. T., Willson, M. F. et al. 2002. Pacific salmon in aquatic and terrestrial ecosystems. - BioScience 52: $917-928$.

Green, R. N. and Klinka, K. 1994. A field guide to site identification and interpretation for the Vancouver forest region. - Res. Branch of the Ministry of Forests, Victoria, British Columbia.

Hébant, C. 1977. The conducting tissues of bryophytes. - J. Cramer, Germany.

Helfield, J. M. and Naiman, R. J. 2001. Effects of salmonderived nitrogen on riparian forest growth and implications for stream productivity. - Ecology 82: 2403-2409. 
Hietz, P., Wanek, W., Wania, R. et al. 2002. Nitrogen-15 natural abundance in a montane cloud forest canopy as an indicator of nitrogen cycling and epiphyte nutrition. - Oecologia 131: $350-355$.

Hikosaka, K. and Hirose, T. 2000. Photosynthetic nitrogen-use efficiency in evergreen broad-leaved woody species coexisting in a warm-temperate forest. - Tree Physiol. 20: 12491254 .

Hilderbrand, G. V., Hanley, T. A., Robbins, C. T. et al. 1999. Role of brown bears (Ursus arctos) in the flow of marine nitrogen into a terrestrial ecosystem. - Oecologia 121: 546550.

Hobbie, E. A., Macko, S. A. and Williams, M. 2000. Correlations between foliar $\delta^{15} \mathrm{~N}$ and nitrogen concentrations may indicate plant-mycorrhizal interactions. - Oecologia 122: $273-283$.

Hocking, M. D. and Reimchen, T. E. 2002. Salmon-derived nitrogen in terrestrial invertebrates from coniferous forests of the Pacific northwest. - BMC Ecol. 2:4 [http://www. biomedcentral.com/1472-6785/2/4]

Jones, C. G., Lawton, J. H. and Shachak, M. 1994. Organisms as ecosystem engineers. - Oikos 69: 373-386.

Jonsson, G. 1997. Riparian bryophyte vegetation in the Cascade mountain range, Northwest U.S.A.: patterns at different spatial scales. - Can. J. Bot. 75: 744-761.

Kielland, K. 1997. Role of free amino acids in the nitrogen economy of arctic cryptograms. - Ecoscience 4: 75-79.

Kline, T. C., Goering, J. J., Mathisen, O. A. et al. 1990. Recycling of elements transported upstream by runs of Pacific salmon: I. $\delta^{15} \mathrm{~N}$ and $\delta^{13} \mathrm{C}$ evidence in the Sashin creek, southeastern Alaska. - Can. J. Fish. Aquat. Sci. 47: $136-144$.

Kline, T. C., Goering, J. J., Mathisen, O. A. et al. 1993. Recycling of elements transported upstream by runs of Pacific salmon: II. $\delta^{15} \mathrm{~N}$ and $\delta^{13} \mathrm{C}$ evidence in the Kvichak river watershed, Bristol Bay, southwestern Alaska. - Can. J. Fish. Aquat. Sci. 50: 2350-2365.

Klinka, K., Krajina, V. J., Ceska, A. et al. 1989. Indicator plants of British Columbia. - Univ. of British Columbia Press, Vancouver.

Leishman, M. R. and Wild, C. 2001. Vegetation abundance and diversity in relation to soil nutrients and soil water content in Vestfold Hills, east Antarctica. - Antarct Sci. 13: 126134.

Mamolos, A. P. and Veresoglou, D. S. 2000. Patterns of root activity and responses of species to nutrients in vegetation of fertile alluvial soil. - Plant Ecol. 148: 245-253.

Manzon, C. I. and Marshall, D. E. 1981. Catalogue of salmon streams and spawning escapements of statistical area 7 (Bella Bella): Fisheries and marine service data report no. 159. - Enhancement Services Branch, Dept of Fisheries and Oceans, Vancouver, British Columbia.

Mathewson, D. D., Hocking, M. D. and Reinchen, T. E. 2003. Nitrogen uptake in riparian plant communities across a sharp ecological boundary of salmon density. - BMC Ecol. 3:4 [http://www.biomedcentral.com/1472-6785/3/4].

Mathisen, O. A., Parker, P. L., Goering, J. J. et al. 1988. Recycling of marine elements transported into freshwater by anadromous salmon. Verh. Int. Ver. Limnol. 18: 10891095.

McKane, R. B., Johnson, L. C., Shaver, G. R. et al. 2002. Resource-based niches provide a basis for plant species diversity and dominance in arctic tundra. - Nature 415: 68 71.

Michelsen, A., Quarmby, C., Sleep, D. et al. 1998. Vascular plant ${ }^{15} \mathrm{~N}$ natural abundance in heath and forest tundra ecosystems is closely correlated with presence and type of mycorrhizal fungi in roots. - Oecologia 115: 406-418.

Nadelhoffer, K. J. and Fry, B. 1994. Nitrogen isotope studies in forest ecosystems. - In: Lajtha, K. and Michener, R. H. (eds), Stable isotopes in ecology and environmental science. Blackwell, pp. 22-44.
Naiman, R. J., Bilby, R. E., Schindler, D. E. et al. 2002. Pacific salmon, nutrients, and the dynamics of freshwater and riparian ecosystems. - Ecosystems 5: 399-417.

Näsholm, T., Ekblad, A., Nordin, A. et al. 1998. Boreal forest plants take up organic nitrogen. - Nature 392: 914916.

Oechel, W. C. and Van Cleve, K. 1986. The role of bryophytes in nutrient cycling in the taiga. - In: Van Cleve, K., Chapin, F. S. III, Flanagan, P. W. et al. (eds), Forest ecosystems in the Alaskan taiga. Ecological Studies 57. Springer, pp. $121-137$

O'Keefe, T and Edwards, R. T. 2003. Evidence for hyporheic transfer and removal of marine-derived nutrients in a sockeye stream in southwest Alaska. - In: Stockner, J. G. (ed.), Nutrients in salmonid ecosystems: sustaining production and biodiversity. Am. Fish. Soc., Symp. 34, Bethuseda, Maryland, pp. 99-107.

Peterson, B. J. and Fry, B. 1987. Stable isotopes in ecosystem studies. - Annu. Rev. Ecol. Syst. 18: 293-320.

Pojar, J. and MacKinnon, A. 1994. Plants of coastal British Columbia. - Lone Pine Publishing, Vancouver, BC.

Raven, P. H., Evert, R. F. and Eichhorn, S. E. 1992. Biology of plants, 5th ed. - Worth Publishers, New York.

Reich, P. B., Walters, M. B. and Ellsworth, D. S. 1997. From tropics to tundra: global convergence in plant functioning. - Proc. Natl Acad. Sci. 94: 13730-13734.

Reimchen, T. E. 1994. Further studies of black bear and chum salmon in stream and estuarine habitats at Bag Harbour, Gwaii Haanas. - Can. Parks Service Rep. 1994.

Reimchen, T. E. 2000. Some ecological and evolutionary aspects of bear-salmon interactions in coastal British Columbia. - Can. J. Zool. 78: 448-457.

Reimchen, T. E., Mathewson, D., Hocking, M. D. et al. 2003. Isotopic evidence for enrichment of salmon-derived nutrients in vegetation, soil and insects in riparian zones in coastal British Columbia. - In: Stockner, J. G. (ed.), Nutrients in salmonid ecosystems: sustaining production and biodiversity. Am. Fish. Soc., Symp. 34. Bethuseda, Maryland, pp. 59-69.

Robinson, D. 2001. $\delta^{15} \mathrm{~N}$ as an integrator of the nitrogen cycle. - Trends Ecol. Evol. 16: 153-162.

Rydin, H. and Clymo, R. S. 1989. Transport of carbon and phosphorus compounds about Sphagnum. - Proc. R. Soc. Lond. B 237: 63-84.

Schulze, E.-D., Chapin, F. S. III and Gebauer, G. 1994. Nitrogen nutrition and isotope differences among life forms at the northern treeline of Alaska. - Oecologia 100: 406412 .

Shaw, J. A. and Goffinet, B. (eds). 2000. Bryophyte biology. - Cambridge Univ. Press.

Soares, A. and Pearson, J. 1997. Short-term physiological responses of mosses to atmospheric ammonium and nitrate. - Water Air Soil Pollut. 93: 225-242.

Stockner, J. G. and Ashley, K. I. 2003. Salmon nutrients: closing the circle. Am. Fish. Soc. Symp. 34: 3-15. - In: Stockner, J. G. (ed.). Nutrients in salmonid ecosystems: sustaining production and biodiversity. - Am. Fish. Soc., Symp. 34, Bethuseda, Maryland, pp. 3-15.

Tamm, C. O. 1953. Growth, yield and nutrition in carpets of a forest moss (Hylocomium splendens). - Medd. Statens Skogsforskningsinst. 43: 1-140.

Weber, M. G. and Van Cleve, K. 1981. Nitrogen dynamics in the forest floor of interior Alaska black spruce ecosystems. - Can. J. For. Res. 11: 743-751.

Weber, M. G. and Van Cleve, K. 1984. Nitrogen transformations in feather moss and forest floor layers of interior Alaska black spruce ecosystems. - Can. J. For. Res. 14: 278 290.

Wells, J. M. and Brown, D. H. 1996. Mineral nutrient recycling within shoots of the moss Rhytidiadelphus squarrosus in relation to growth. - J. Bryol. 19: 1-17.

Williams, B., Silcock, D. and Young, M. 1999. Seasonal dynamics of $\mathrm{N}$ in two Sphagnum moss species and the 
underlying peat treated with ${ }^{15} \mathrm{NH}_{4}^{15} \mathrm{NO}_{3}$. - Biogeochemistry $45: 285-302$.

Willson, M. F., Gende, S. M. and Marston, B. H. 1998. Fishes and the forest: expanding perspectives of fish-wildlife interactions. - Bioscience 48: 455-462.
Wipfli, M. S., Hudson, J. and Caouette, J. 1998. Influence of salmon carcasses on stream productivity: response of biofilm and benthic macroinvertebrates in southeastern Alaska, U.S.A. - Can. J. Fish. Aquat. Sci. 55: $1503-1511$. 